\title{
GENETIC ANALYSIS OF Melipona quadrifasciata LEP. (HYMENOPTERA: APIDAE, MELIPONINAE) WITH RAPD MARKERS
}

\author{
WALDSCHMIDT, A. M., ${ }^{1}$ MARCO-JUNIOR, P., ${ }^{2}$ \\ BARROS, E. G. ${ }^{2}$ and CAMPOS, L. A. O. ${ }^{2}$ \\ ${ }^{1}$ Departamento de Ciências Biológicas, Universidade Estadual do Sudoeste da Bahia (UESB), Campus de Jequié, \\ CEP 45200-000, Jequié, BA, Brazil \\ ${ }^{2}$ Departamento de Biologia Geral, Universidade Federal de Viçosa (UFV), CEP 36571-000, Viçosa, MG, Brazil \\ Correspondence to: Ana Maria Waldschmidt, Departamento de Ciências Biológicas, UESB, Campus de Jequié, \\ CEP 45200-000, Jequié, BA, Brazil, e-mail: amaria @uesb.br \\ Received August 28, 2001 - Accepted February 19, 2002 - Distributed November 30, 2002
}

(With 1 figure)

\begin{abstract}
Melipona quadrifasciata ("mandaçaia") can be subdivided into two subspecies: M. q. anthidioides and M. q. quadrifasciata. In the present study we used RAPD markers to estimate intercolonial genetic variation among 69 colonies of Melipona quadrifasciata. Ten workers per colony were analyzed. The intercolony genetic distances based on RAPD markers ranged from 29.5\% (colonies collected in the State of São Paulo vs colonies from the State of Minas Gerais) to 34.2\% (São Paulo vs Santa Catarina). These results indicate a high genetic similarity among the colonies analyzed. According to the genetic distances two different groups could be distinguished. The first containing the samples from Santa Catarina region and the second, samples from Paraná, São Paulo, Minas Gerais, and Espírito Santo. Based on the molecular analysis, bees belonging to the different subspecies M. q. quadrifasciata (from Santa Catarina) and M. q. anthidioides (from the other regions) were distinguished.
\end{abstract}

Key words: Hymenoptera, stingless bees, Melipona quadrifasciata, RAPD, genetic distance.

\section{RESUMO}

\section{Análise genética de Melipona quadrifasciata Lep. (Hymenoptera: Apidae, Meliponinae)} por meio de marcadores RAPD

A abelha Melipona quadrifasciata Lep., conhecida popularmente como "mandaçaia", apresenta duas subespécies: Melipona quadrifasciata anthidioides e Melipona quadrifasciata quadrifasciata. Utilizandose marcadores RAPD, foram calculadas as distâncias genéticas entre 69 colônias de Melipona quadrifasciata. Foram coletadas 10 operárias de cada colônia. As distâncias genéticas entre as colônias dessas regiões variaram de 29,5\% (entre São Paulo e Minas Gerais) a 34,2\% (entre São Paulo e Santa Catarina), indicando alto grau de similaridade genética entre as abelhas provenientes de diferentes regiões. De acordo com a distância genética, dois grupos podem ser distinguidos, um pertencente à subespécie $M$. q. quadrifasciata (região de Santa Catarina) e outro pertencente à subespécie $M$. q. anthidioides (demais regiões amostradas).

Palavras-chave: Hymenoptera, abelhas sem ferrão, Melipona quadrifasciata, RAPD, distância genética. 


\section{INTRODUCTION}

Melipona quadrifasciata Lep. ("mandaçaia") is a stingless bee species occurring along the coast of Brazil from the State of Paraíba to the State of Rio Grande do Sul. It can be subdivided into two subspecies: Melipona quadrifasciata anthidioides and Melipona quadrifasciata quadrifasciata. The main morphological difference between the two subspecies is the presence of continuous yellow tergal bands (three to five) from the third to the sixth segment in workers and males of Melipona quadrifasciata quadrifasciata, and interrupted yellow bands (two to five) in Melipona quadrifasciata anthidioides (Schwarz, 1948)

The subspecies M. q. quadrifasciata is found in the Southern States (São Paulo, Paraná, and Santa Catarina), mainly in high altitude cold regions. In the South and Minas Gerais it can be found at altitudes above $1,500 \mathrm{~m}$. This subspecies also occurs along the northern coast of São Paulo (Moure \& Kerr, 1950). M. q. anthidioides occurs more to the north, i.e., in Minas Gerais and Rio de Janeiro, in habitats with higher temperatures.

In regions of the State of São Paulo and in the southern part of Minas Gerais there is a hybridization zone where hybrids with intermediate patterns of tergal bands can be found. In Minas Gerais M. q. anthidioides can be found more often. However, in the northern region of the State, $M$. quadrifasciata with a banding pattern similar to that of M. q. quadrifasciata was found, inhabiting warm low regions at 500 to $700 \mathrm{~m}$ (Melo \& Campos, 1987).

Randomly amplified polymorphic DNA (RAPD) markers have been used to distinguish bee species. Suazo et al. (1998) identified specific RAPD markers able to differenciate between European and African Apis mellifera races. Vasconcelos (1998), also using RAPD markers, determined the genetic distances between populations of Melipona rufiventris and separated the populations into three distinct groups. This technique has also been utilized to estimate genetic variability in five species of microhymenopterans of the genus Anophes and Trichograma, employed in biological control (Landry et al., 1993), and for the study of genetic variability in Megachile rotundata (Lu \& Rank, 1996). The technique was used to separate two ant species (Solenopsis invicta and Solenopsis richteri) and to detect the hybrid zone formed by the crosses between these species (Shoemaker et al., 1994).

Compared to other insects, hymenoptera usually present low variability because of factors such as haplodiploidy, increased selection due to hemizygous expression of deleterious recessive alleles in males, and high genetic drift due to the reduced effective population size (Shoemaker $e t$ al., 1994). In this case, the use of molecular markers, such as the RAPD markers which include the non-coding regions of the genome, is quite useful for the study of variability because it enables detection of numerous, polymorphisms.

In the present study we evaluated the genetic dissimilarity between $M$. q. quadrifasciata and $M$. q. anthidioides on the basis of molecular data obtained for populations collected in Brazil in various regions where they are distributed.

\section{MATERIAL AND METHODS}

\section{Genetic material}

We used 69 M. quadrifasciata colonies whose origins are listed in Table 1. The bees from Itaiópolis (Santa Catarina) and Londrina (Paraná) belong to the subspecies M. q quadrifasciata. The remaining ones belong to the subspecies M.q. anthidioides, except for two colonies from Januária (Northern Minas Gerais) which present a banding pattern similar to that of M. q. quadrifasciata. Ten workers were collected, on average, from each colony and used for genomic DNA extraction. The DNA bulks obtained by mixing equal amounts of DNA from 10 individuals from each colony were used for the analysis of genetic distances among colonies.

\section{DNA extraction and amplification}

Genomic DNA was extracted according to Waldschmidt et al. (1997) and amplified by the PCR-RAPD according to Williams et al. (1990). The reaction mixture $(25 \mu \mathrm{ml})$ consisted of $25 \mathrm{ng}$ genomic DNA, $2.0 \mathrm{mM} \mathrm{MgCl}, 10 \mathrm{mM}$ Tris, $\mathrm{pH}$ 8.0, $50 \mathrm{mM} \mathrm{KCl}, 0.1 \mathrm{mM}$ of each deoxyribonucleoside triphosphate (dATP, dTTP, dCTP, dGTP), $0.4 \mu \mathrm{M}$ primer (Operon Technologies Alameda, AL, USA), and one unit Taq polimerase. The mixture was incubated in a thermocycler model PTC-100 (MJ Research) programmed for 40 cycles, each consisting of a denaturation step (15 seconds at $94^{\circ} \mathrm{C}$ ), a pairing step (30 seconds at $\left.35^{\circ} \mathrm{C}\right)$, and an extension step $\left(1 \mathrm{~min}\right.$ at $\left.72^{\circ} \mathrm{C}\right)$. 
TABLE 1

Origin, number of colonies and subspecies of Melipona quadrifasciata.

\begin{tabular}{|l|l|c|l|}
\hline \multicolumn{1}{|c|}{ States } & \multicolumn{1}{c|}{ Locations } & N. of colonies sampled & \multicolumn{1}{c|}{ Subspecies } \\
\hline Espírito Santo & Domingos Martins & 18 & M.q. anthidioides \\
\hline Minas Gerais & Januária & 2 & similar a M. q. quadrifasciata \\
\hline Minas Gerais & Oliveira & 2 & M. q. anthidioides \\
\hline Minas Gerais & Porto Firme & 4 & M. q. anthidioides \\
\hline Minas Gerais & Uberlândia & 2 & M. q. anthidioides \\
\hline Paraná & Curitiba & 16 & M. q. anthidioides \\
\hline Paraná & Londrina & 1 & M. q. quadrifasciata \\
\hline São Paulo & Cunha & 4 & M.q. anthidioides \\
\hline São Paulo & Pilar do Sul & 2 & M.q. anthidioides \\
\hline São Paulo & Ribeirão Preto & 1 & M.q. anthidioides \\
\hline Santa Catarina & Itaiópolis & 17 & M.q. quadrifasciata \\
\hline Total & & 69 & \\
\hline
\end{tabular}

An extra extension step was performed at the end of the 40 cycles $\left(7 \mathrm{~min}\right.$ at $72^{\circ} \mathrm{C}$ ). The reaction products were separated by electrophoresis on $1.2 \%$ agarose gel containing $10 \mu \mathrm{g} / \mathrm{ml}$ ethidium bromide immersed in TBE buffer $(90 \mathrm{mM}$ Tris-borate, 1 $\mathrm{mM}$ EDTA, $\mathrm{pH}$ 8.0). The DNA bands were visualized under ultraviolet light and photographed with the aid of a polaroid camera.

\section{Statistical analysis}

Analysis of the molecular data for individuals and bulks involved interpretation of the amplified genomic DNA bands, with the presence of a band being coded as 1 and its absence as 0 . The binary data matrix thus generated was then used to calculate the coefficient of simple coincidence $\left(S_{i j}\right)$, in which the genetic similarity between the ith and $\mathrm{jth}$ individuals is given by:

Coefficient of simple coincidence $\left(S_{i j}\right)$

$$
S_{i j}=\left(\frac{a+d}{a+b+c+d}\right)
$$

where

$\mathrm{a}=$ Number of bands present in the two samples (1.1) $\mathrm{b}=$ Number of bands present in the first sample and absent in the second (1.0)

$\mathrm{c}=$ Number of bands absent in the first sample and present in the second (0.1) and

$\mathrm{d}=$ Absence of bands in both populations (number of counts of type 0.0 concordance).

In the present study we used the coefficient of similarity that considered the $d$ (doble absence) component. We assumed that the absence of amplification in the two populations as evidence of homology (Skroch et al., 1992).

The genetic similarity $\left(\mathrm{S}_{i j}\right)$ in (1) was then converted to genetic distance $\left(D_{i j}\right)$, using the arithmetic complement of similarity (Dias, 1998) given by the expression:

$$
D_{i j}=1-S_{i j}
$$

These coefficients were used for cluster analysis by the UPMGA method (Dias, 1998).

The proportion of polymorphic bands was used to estimate genetic diversity in the populations studied, using the jacknife statistical test, which calculates successive pseudovalues estimated after removing each element from the sample. The mean and variance of these pseudovalues are used as an estimate of variance (Manly, 1991). 


\section{RESULTS AND DISCUSSION}

For the analysis of intercolony distance we used 29 primers that produced 139 monomorphic bands and 112 polymorphic bands. The mean number of polymorphic bands produced by each primer was 3.4 .

Pairwise, genetic distances between colonies from the various regions ranged from $29.5 \%$ (between São Paulo and Minas Gerais) to $34.2 \%$ (between São Paulo and Santa Catarina), indicating the existence of a high degree of genetic similarity between the bees from the different locations (Table 2). These data agree with the low enzymatic variability detected in previous studies on hymenopterans (Metcalf et al., 1975). The intercolony genetic distances obtained may possibly be due to the fact that the populations were so large (even allopatric) that no great allelic alteration occurred between them, implying a small genetic distance separating them. In addition, the occurrence of intense gene flow and a possibly recent separation between populations reduced the variation among them (Slatkin, 1987).

The dendrogram in Fig. 1 shows that the Santa Catarina region was separated from the remaining ones, with the lowest genetic distance $(29.5 \%)$ being found between the colonies from Minas Gerais and São Paulo. Morphometric data also separated the subspecies $M$. q. quadrifasciata from $M$. $q$. anthidioides (Waldschmidt et al., in press) and we may conclude that the use of bulks in molecular analysis was an efficient strategy for the demonstration of variability between $M$. quadrifasciata subspecies.
Both molecular and morphometric (Waldschmidt et al., in press) analyses not only indicated separation of the bees belonging to the subspecies M. q. quadrifasciata (Santa Catarina region) from those belonging to the subspecies $M$. q. anthidioides (remaining regions), but also revealed little distance separating colonies collected in the various regions of Brazil. These studies on genetic variability are very important as they can be helpful in developing handling systems that guarantee diversity of the species.

The results of the analysis of proportion of polymorphic bands demonstrated that the genetic variability ranged from $44.2 \%$ for the Paraná colonies to $47.2 \%$ for the Minas Gerais colonies, an insignificant difference.

The small variations detected among the colonies studied may also be due to the fact that approximately 500 years ago all the areas considered in this study were covered by the Atlantic Forest. Adaptation to similar habitats may have given origin to low genetic variability among populations which, although geographically distant, were adapted to similar environments. However, the RAPD technique does not permit making this inference since the adaptive value of the DNA regions amplified by it is unknown.

Maintenance of the genetic diversity of bees is very important because these organisms are particularly sensitive to the reduction of their genetic base. Homozygozity at the loci involved in the process of sex determination, for instance, leads to the appearance of diploid males.

TABLE 2

Genetic distances (\%) based on RAPD data among $M$. quadrifasciata colonies from five regions of Brazil.

\begin{tabular}{|l|c|c|c|c|c|}
\hline & Minas Gerais & São Paulo & Paraná & Espírito Santo & Santa Catarina \\
\hline Minas Gerais & 0 & & & & \\
\hline São Paulo & 29.5 & 0 & & & \\
\hline Paraná & 30.0 & 30.0 & 0 & & \\
\hline Espírito Santo & 30.1 & 30.7 & 30.5 & 0 & \\
\hline Santa Catarina & 33.8 & 34.2 & 33.7 & 31.1 & 0 \\
\hline
\end{tabular}




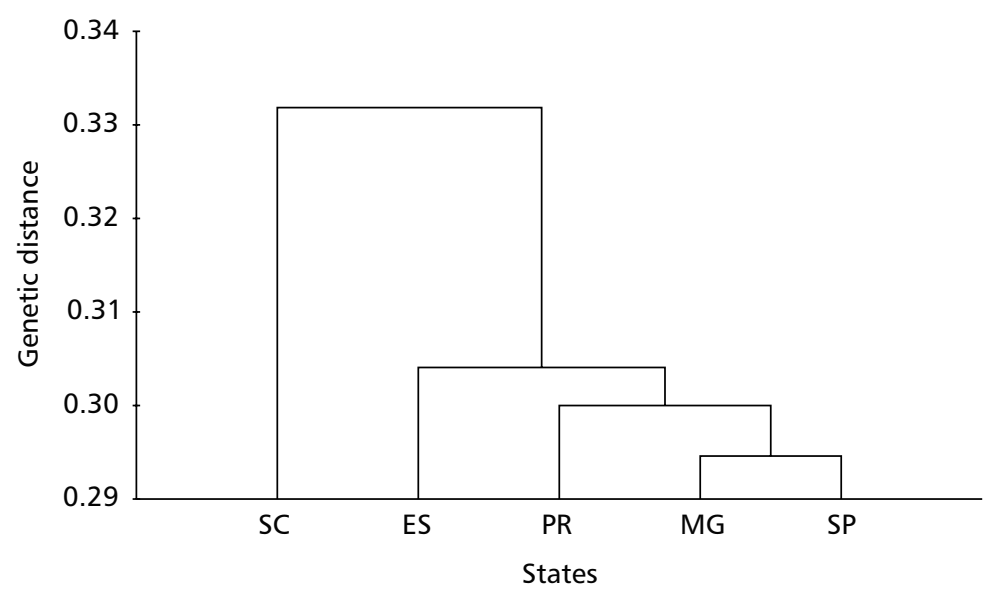

Fig. 1 - Dendrogram generated by UPMGA illustrating the genetic distances between regions, calculated from RAPD data obtained from bulk DNA samples of 10 individuals per $M$. quadrifasciata colony, amplified with 29 primers.

These are usually sterile and almost blind, have a very reduced number of spermatozoa, and are either killed by the workers when they emerge from the comb (Melipona) or eaten by the workers before they reach three days of larval age (Apis mellifera) (Kerr et al., 1996). For this reason, destruction of the habitat due to loss, degradation, or fragmentation may be responsible for the extinction of some bee species. Although habitat destruction is occurring on a global level, tropical environments are being devastated more intensely. Erwin (1988) estimates that an area of the tropical rain forest the size of Honduras is lost every year.

Acknowledgments - We are grateful to Dergam Abdala dos Santos and Luis Antonio Dias for valuable criticisms and suggestions, and to Sebastião Gonzaga, Yasmine Antoniolli, Vera Imperatriz-Fonseca, and Davi Said Aidar for the Melipona quadrifasciata samples. This research was supported by FAPEMIG and CNPq.

\section{REFERENCES}

DIAS, L. A. S., 1998, Análises multidimensionais. In: A. C. Alfenas (ed.), Eletroforese de isoenzimas e proteínas afins. UFV, Viçosa, MG, pp. 405-475.

ERWIN, T. L., 1988, The tropical forest canopy: the heart of biotic diversity. In: E. O. Wilson \& F. M. Peter (eds.), Biodiversity. National Academy Press, Washington, D.C., pp. 123-129.
KERR, W. E., ALMEIDA, G. A. \& NASCIMENTO, V. A., 1996, Abelha Uruçu. Biologia, manejo e conservação. Fundação Acangaú, Belo Horizonte, p. 141.

LANDRY, B. S., DEXTRAZE, L. \& BOIVIN, G., 1993, Random amplified polymorphic DNA markers for DNA fingerprinting and genetic variability assessment of minute parasitic wasp species (Hymenoptera: Mymaridae and Trichogrammatidae) used in biological control programs of phytophagous insects. Genome, 36: 580-587.

LU, R. \& RANK, G. H., 1996, Use of RAPD analyses to estimate population genetic parameters in the alfalfa leafcutting bee, Megachile rotundata. Genome, 39: 655-663.

MANLY, B. F. J., 1991, Randomatization and Monte Carlo methods in biology. Chapman and Hall, London.

MELO, G. A. R. \& CAMPOS, L. A. O., 1987, Variação do padrão de faixas na população de Melipona quadrifasciata Lepeletier, 1936, no Estado de Minas Gerais (Hymenoptera, Apidae, Meliponinae). In: Anais do $14^{\circ}$ Congresso Brasileiro de Zoologia, Juiz de Fora, p. 76.

METCALF, R. A., MARLIN, J. C. \& WHITT, G. S., 1975, Low levels of genetics heterozygosity in hymenoptera. Nature (London), 257: 792-794.

MOURE, J. S. \& KERR, W. E., 1950, Sugestões para a modificação da sistemática do gênero Melipona (Hymenoptera, Apoidea). Dusenia, 12: 105-129.

SCHWARZ, H., 1948, Stingless bees (Meliponidae) of the Western Hemisphere. Bulletin of the American Museum of Natural History, New York, p. 167.

SHOEMAKER, D. D., COSTA, J. T. \& ROSS, K. G., 1994, Estimates of heterozygosity in two social insects using a large number of electrophoretic markers. J. Heredity, 69: $573-582$. 
SKROCH, P., TIVANG, J. \& NIENHUIS, J., 1992, Analysis of genetic relations using RAPD marker data. In: Proceedings Joint Plant Breeding Symposia Series, Minneapolis. Crop Science Society of America, American Society for Horticultural Science, American Genetic Association, Minneapolis, pp. 26-30.

SLATKIN, M., 1987, Gene flow and geographic structure of natural population. Science, 236: 787-792.

SUAZO, A., MCTIERNAN, R. \& HALL, H. G. 1998, Differences between African and European honey bees (Apis mellifera L.) in random amplified polymorphic DNA (RAPD). J. Heredity, 89: 32-36.
VASCONCELOS, S. M., 1998, Divergência genética entre populações de M. rufiventris (Hymenoptera, Apidae, Meliponinae). Dissertação de Mestrado em Genética e Bioquímica, Universidade Federal de Uberlândia, Uberlândia, 49p.

WALDSCHMIDT, A. M., SALOMÃO, T. M. F., BARROS, E. G. \& CAMPOS, L. A. O., 1997, Extraction of genomic DNA from Melipona quadrifasciata (Hymenoptera: Apidae, Meliponinae). R. Bras. Genet., 20: 421-423.

WILLIAMS, J. G. K., KUBELIK, A. R. \& LIVAR, K. J., 1990, DNA polymorphisms amplified by arbritary primers are useful as genetic markers. Nucl. Acids Res., 18: 6531-6535. 